DOI: $\underline{\text { https://doi.org/10.33739/2587-5434-2021-3-1-26-36 }}$

\title{
AUTONOMOUS APHORISMS (APHORISM IN THE NON-APHORISTIC TEXT)
}

\author{
Eugene E. Ivanov \\ PhD of Philological Sciences, Associate Professor, \\ Head of the Department of Theoretical and Applied Linguistics, \\ Mogilev State A. Kuleshov University \\ (Mogilev, Republic of Belarus) \\ e-mail: ivanov-msu@mail.ru \\ Elena G. Teslenko \\ Research Student of the Department of Theoretical and Applied Linguistics, \\ Mogilev State A. Kuleshov University \\ (Mogilev, Republic of Belarus) \\ e-mail: ling-msu@mail.ru
}

\begin{abstract}
The article deals with the concept of the autonomy of the aphorisms as the microtext in the macrotext (literary text). The variety of the autonomous aphorisms (absolutely autonomous and relatively autonomous aphoristic units), methods and means of their introduction in the non-aphoristic context are described in the article (based on W. Shakespeare's works).
\end{abstract}

Key words: aphorism, microtext, macrotext, literary text, non-aphoristic context, autonomy, W. Shakespeare's works.

\section{АВТОНОМНЫЕ АФОРИЗМЫ (АФОРИЗМ В НЕАФОРИСТИЧЕСКОМ ТЕКСТЕ)}

\author{
Е. Е. Иванов \\ кандидат филологических наук, доцент \\ заведующий кафедрой теоретической и прикладной лингвистики, \\ Могилёвский государственный университет имени А. А. Кулешова \\ (Могилёв, Республика Беларусь) \\ e-mail: ivanov-msu@mail.ru \\ Е. Г. Тесленко \\ исследователь кафедры теоретической и прикладной лингвистики \\ Могилёвский государственный университет имени А.А. Кулешова \\ (Могилёв, Республика Беларусь) \\ e-mail: ling-msu@mail.ru
}

\footnotetext{
Аннотация. В статье определяется понятие автономности афоризма как микротекста в макротексте (литературном тексте), описываются разновидности автономных афоризмов (абсолютно автономные и относительно автономные единицы), способы и средства их введения в неафористический контекст (на материале произведений Уильяма Шекспира). 
Ключевые слова: афоризм, микротекст, макротекст, художественный текст, неафористический контекст, автономность, произведения У. Шекспира.

INTRODUCTION. Obligatory properties of aphorism are one phrase structure, generalized meaning, discursive autonomy (Ivanov 2020). The main (differential) property of aphorism as an object of linguistics is the generalized meaning, which in relation to the expressed reality has a specific character - universal character (Ivanov 2016b). This property characterizes aphorisms as a one-phrase texts (Ivanou 2019a), determines their discursive autonomy (Ivanov 2019; Ivanou 2019b).

The problem of "taking-out of an aphorism from the text" which was raised in the linguistics in the 80-ies (Epshtein 1987, 43) is still unsettled in modern aphoristics. This question acquires special actuality in connection with the increase of research interest to author's heritage, writer's idiostyle (Pfeifer 1990; Jarmuszkiewicz 2015; Kudra 2015; Gluchanko 2014; Gluchanko 2017a; Gluchanko 2017b). The distinctive feature of the language of a number of authors is "filling the text with overfactual or universal (aphoristic) content with the help of appropriate language means" (Ivanov 2006, 78).

Aphorisms are divided into "original literary forms" and "utterances, taken out from the definite literary content" (Epshtein 1987, 43) in other words "separate" and "introductory" aphorisms (Fedorenko \& Sokolskaia 1990, 86). The aphorism is a special type of the text and it possesses the following functional peculiarity: "one and the same aphorism can be an original speech work and a microtext - a constituent part of a macrotext" (Elenevskaia 1983, 2).

A considerable number of aphorisms aren't created as independent units, but used in the context of non-aphoristic works. Such kinds of aphorisms can be considered to be only "potential texts", their actualization "as texts is possible only outside author's context of their usage, where aphorisms' contents and the structure are on the level of their formation" (Ivanov 2006, 77).

So there is a problem of taking-out of the aphorism from the context and of possible content and structural changes of an aphoristic utterance. The sense of an aphorism "goes beyond the context" (Gluchanko 2019), is "free from situational and contextual boundaries" (Epshtein 1987: 43), has overtextual nature. But structurally an aphorism is formed in the text in a different way, it is often transformed. In order to single out an aphorism from the text it is necessary to define its bounds and to choose the right form of its actualization beyond the author's context (Ivanov 2007, 30; Ivanov 2013).

All the individual author's aphorisms are divided into two groups according to the relations between the utterance and the text. Many of the aphoristic utterances don't depend on the context in content and form. They can be taken out of it easily without any changes of their semantics and lexical-grammatical structure. Such aphorisms while being extracting from the text don't break its content and formal integrity, although they can make lacunae of different significance in the whole outline of the narration or reflection. So we qualify them as autonomous regarding the context (Ivanov \& Teslenko 2013a). 
The majority of the aphoristic utterances are subjected to semantic and/or structural modifications in the text. They can't be taken out of it easily and require certain reorganizations or transformations in order to reconstruct the "initial" aphorism. These utterances we define as the context-dependent aphoristic utterances (Ivanov \& Teslenko 2013b).

The phenomenon of the autonomy of the aphoristic utterance in the non-aphoristic context, as well as the transformation changes of the context-dependent aphoristic utterances in literary texts are of interest for researchers both within the linguistics of the text and linguistic theory of the aphorism (Ivanov 2016a, 128-149).

The aim of this article is to describe the variety of autonomous aphorisms, ways and means of their introduction into the non-aphoristic context, as well as the system of transformation methods as ways of the context-dependent aphorisms introduction into the non-aphoristic context. The research is based on a number of W. Shakespeare's works, the individual style of this author is extremely rich in aphoristic utterances.

On the basis of random selection there have been chosen 9 plays by W. Shakespeare («Twelfth Night», «Much Ado about Nothing», «The Merry Wives of Windsor», «All's Well That Ends Well», «Troilus and Cressida», «The Comedy of Errors», «Two Gentlemen of Verona», «Winter's Tale», «Loves Labours Lost»), the total volume of the analyzed texts comes to 460 nominal pages. There are about 345 individual author's aphorisms, in which 94 are autonomous regarding the context $(27,0 \%$ in total amount of individual author's aphorisms) and 251 contextdependent aphoristic utterances (correspondently 73,0\%).

\section{Absolutely autonomous aphoristic utterances}

Those aphorisms the autonomy of which is nothing restricted by can be qualified as absolutely autonomous. They don't depend on the context in content or structure, they aren't transformed while being introduced into the text by the author. They are easily taken out of the text not breaking its contents and grammar form, they don't make semantic or syntactic lacunae. Every third autonomous aphorism in the analyzed texts is absolutely autonomous (32,0\% in the amount of the autonomous aphorisms). E.g.: King. 'Tis only title thou disdain'st in her, the which I can build up. Strange is it that our bloods, Of colour, weight, and heat, pour'd all together, Would quite confound distinction, yet stand off In differences so mighty. If she be All that is virtuous, save what thou dislikest, A poor physician's daughter, thou dislikest Of virtue for the name: but do not so: From lowest place when virtuous things proceed, The place is dignified by the doer's deed: Where great additions swell's, and virtue none, It is a dropsied honour. Good alone Is good without a name. Vileness is so: The property by what it is should go, Not by the title. (AWTEW, A 2, S 3).

Absolutely autonomous aphorisms can perform separate reply in the dialogue. In such cases they cut into the text and not having special marks of their connection with the context are perceived as quite independent, isolated in the text. It is especially vivid when such aphorisms go one after the other in a dialogue. E.g.: Helena. I do affect a sorrow indeed, but I have it too. Lafeu. Moderate lamentation is the right of the dead, excessive grief the enemy to the living. Countess. If the living be enemy to the grief, the excess makes it soon mortal. (AWTEW, A 1, S 1). 
Content and form isolation of the absolutely autonomous aphoristic utterances in the text increases when they are composite sentences with different types of connection by their syntactic structure. It contributes to the perception of them as separate independent texts. E.g.: First Lord. How mightily sometimes we make us comforts of our losses! Second Lord. And how mightily some other times we drown our gainin tears! The great dignity that his valour hath here acquired for him shall at home be encountered with a shame as ample. First Lord. The web of our life is of a mingled yarn, good and ill together: our virtues would be proud, if our faults whipped them not; and our crimes would despair, if they were not cherished by our virtues. (Enter Messenger). (AWTEW, A 4, S 3).

Absolutely autonomous aphoristic utterances are used comparatively rarely in the literary texts because of its highly marked overfactual character. They are very close to the separate aphorisms. Absolutely autonomous aphoristic statements are often used as quotes (Ivanou 2011; Ivanou 2018) or as proverbs (Ivanov \& Petrushevskaia 2015; Ivanov \& Petrushevskaia 2016; Ivanov \& Petrushevskaia 2019).

\section{Relatively autonomous aphoristic utterances}

Those aphorisms the autonomy of which is restricted in content and/or form can be qualified as relatively autonomous. The same as absolutely autonomous aphoristic utterances they don't depend on the context, they aren't transformed while being introduced into the text by the author. But when they are taken out of the text they break it one way or another and make semantic and/or syntactic lacunae.

There are $68,0 \%$ of relatively autonomous aphoristic utterances (in the amount of the autonomous aphorisms) in the analyzed texts.

\subsection{Syntactically uncombined relatively autonomous aphoristic utterances}

They (7,5\% in the amount of the autonomous aphorisms) are introduced into the text in the same way as absolutely autonomous aphorisms, but unlike the latter they are related to the context in content.

The existence of such relations is marked by different language means. Depending on the place of language marks of the aphorism content connection with the text three main ways of introduction of syntactically uncombined utterances are distinguished: a) in the prepositional context; b) in the postpositional context; c) in the interpositional context.

While introducing an aphoristic utterance into the prepositional context it plays the role of a key conclusion in a reflection and completes it (such way of introduction occurs more often than the two others). E.g.: Bene. [Advancing from the arbour.] <.. > A man loves the meat in his youth that he cannot endure in his age. Shall quips and sentences and these paper bullets of the brain awe a man from the career of his humour? No; the world must be peopled. When I said I would die a bachelor, I did not think I should live till I were married. Here comes Beatrice. By this day! she's a fair lady: I do spy some marks of love in her. (MAAN, A 2, S 3). The aphorism The world must be 
peopled is included into the internal monologue of the character as an answer to the preceding rhetorical question, as an objection to the previous idea marked by negative pronoun with the meaning of contrast.

Actualization of an aphorism in the postpositional context occurs rarely and is typical mainly for dialogical form of speech when the content of the aphoristic utterance is interpreted in the reply of the other character. E.g.: D. Pedro. She were an excellent wife for Benedick. Leon. $O$ Lord! my lord, if they were but a week married, they would talk themselves mad. D. Pedro. Count Claudio, when mean you to go to church? Claud. To-morrow, my lord. Time goes on crutches till love have all his rites. Leon. Not till Monday, my dear son, which is hence a just seven-night; and a time too brief too, to have all things answer my mind. (MAAN, A 2, S 1). The semantic of the aphorism Time goes on crutches till love have all his rites determines the meaning of the following reply that is marked by the key word time.

The introduction of an aphorism into the interpositional context occurs more often than into the postposition and aims at summing up what was said, finishing the reflection with an argument which appeals to the universal knowledge and creates the basis to complete the monologue or further reflection as well as play a part of stimulus for the definite speech response of the addressee. E.g.: Parolles. Yet am I thankful: if my heart were great, 'Twould burst at this. Captain I'll be no more; But I will eat and drink, and sleep as soft As captain shall: simply the thing I am Shall make me live. Who knows himself a braggart, Let him fear this, for it will come to pass that every braggart shall be found an ass. Rust, sword? cool, blushes! and, Parolles, live Safest in shame! being fool'd, by foolery thrive! There's place and means for every man alive. I'll after them. (AWTEW, A 4, S 3). The aphorism There's place and means for every man alive summarizes the previous text (without breaking content integrity when have been taken out of the context) and causes the following phrase I'll after them which is connected semantically only with the aphorism (while the aphorism semantics doesn't determine only such a continuation).

\subsection{Syntactically combined relatively autonomous aphoristic utterances}

They (60,5\% in the amount of the autonomous aphorisms) are introduced into the text in the same way as absolutely autonomous aphorisms, but unlike the latter they are related to the context in content and syntactically. Aphorisms of this group have the same content relation with the context and the ways of introduction into the text as syntactically uncombined relatively autonomous aphoristic utterances. But syntactically they cannot be taken out of speech without breaking its grammar structure, the grammar structure of the aphorisms in these cases remain unchangeable.

Syntactically combined relatively autonomous aphoristic utterances are parts of composite sentences joined asyndetically and syndetically and connected with other clauses by means of coordination and subordination. The productivity of this group of aphorisms depends on the way of their introduction into the context. 


\subsubsection{Asyndetical connection between an aphorism and other clauses of a composite sentence}

It is used less than syndetical one $(24,5 \%$ in the amount of the autonomous aphorisms) and characterized mostly by relation of coordination than subordination (there are no examples of the latter).

The aphorism is more often build in the composite sentence by means of asyndetical connection in the postposition (12,5\%). E.g.: Olivia. O, what a deal of scorn looks beautiful In the contempt and anger of his lip! A murderous guilt shows not itself more soon Than love that would seem hid: love's night is noon. Cesario, by the roses of the spring, By maidhood, honour, truth and every thing, I love thee so, that, maugre all thy pride, Nor wit nor reason can my passion hide. Do not extort(вымогать, выпыmblвать) thy reasons from this clause, For that I wоо (ухаживать, уговаривать), thou therefore hast no cause, But rather reason thus with reason fetter (оковы), Love sought is good, but given unsought better. (TW, A 3, S 1); Paulina. I care not: It is an heretic that makes the fire, Not she which burns in't. I'll not call you tyrant; But this most cruel usage of your queen, Not able to produce more accusation Than your own weak-hinged fancy, something savours Of tyranny and will ignoble make you, Yea, scandalous to the world. (WT, A 2, S 3).

Comparatively rarely - in the preposition (5,5\%). E.g.: Hector. Be gone, I say: the gods have heard me swear. Cassandra. The gods are deaf to hot and peevish vows: They are polluted offerings, more abhorr'd Than spotted livers in the sacrifice. (T\&C, A 5, S 3).

The aphorism in the interposition is also seldom used (6,5\%). E.g.: Luciana. Perhaps some merchant hath invited him, And from the mart he's somewhere gone to dinner. Good sister, let us dine and never fret: A man is master of his liberty: Time is their master, and, when they see time, They'll go or come: if so, be patient, sister. (COE, A 2, S 1).

Such ways of introduction ratio among syntactically combined relatively autonomous aphoristic utterances in the asyndetical composite sentences can be explained by their closeness to syntactically combined aphoristic utterances. Both of these types of relatively autonomous aphorisms without essential limits can turn into each other due to the absence of proper connectors with the context. Formal indicator of this fact is coincidence of qualitative characteristics of the ways of introduction.

\subsubsection{Syndetical connection between an aphorism and other clauses of a composite} sentence

It is used more often than asyndetical one $(36,0 \%$ in the amount of the autonomous aphorisms) but also characterized mostly by the relation of coordination. At the same time there are a number of examples of syndetical subordinate connection.

The aphorism is more often build in the composite sentence by means of syndetical connection in the postposition (17,0\%). E.g.: Mrs. Page. What! have I 'scaped love-letters in the holiday-time of my beauty, and am I now a subject for them? Let me see. Ask me no reason why I 
love you; for though Love use Reason for his physician, he admits him not for his counsellor. (MWW, A 2, S 1). Subordinate relation is used only in one example. E.g.: Friar. Marry, this well carried shall on her behalf Change slander to remorse; that is some good: But not for that dream I on this strange course, But on this travail look for greater birth. She dying, as it must be so maintain'd, Upon the instant that she was accus'd, Shall be lamented, pitied and excus'd Of every hearer; for it so falls out That what we have we prize not to the worth Whiles we enjoy it, but being lack'd and lost, Why, then we rack the value, then we find The virtue that possession would not show us Whiles it was ours. So will it fare with Claudio: <... (MAAN, A 4, S 1).

Much more seldom we find aphorisms in the preposition (less than 6,5\%). E.g.: Boyet. Proud of employment, willingly I go. Princess. All pride is willing pride, and yours is so. (LLL A2, $\mathrm{S} 1)$. The subordinate relation between clauses of a composite sentence is used twice rarer than the coordinate one. E.g.: Helena. I will stand for 't a little, though therefore I die a virgin. Parolles. There's little can be said in 't; 'tis against the rule of nature. To speak on the part of virginity, is to accuse your mothers; which is most infallible disobedience. He that hangs himself is a virgin: virginity murders itself and should be buried in highways out of all sanctified limit, as a desperate offendress against nature. Virginity breeds mites, much like a cheese; consumes itself to the very paring, and so dies with feeding his own stomach. Besides, virginity is peevish, proud, idle, made of self-love, which is the most inhibited sin in the canon. Keep it not; you cannot choose but loose by't: out with ' $t$ ! within ten year it will make itself ten, which is a goodly increase; and the principal itself not much the worse: away with 't! (AWTEW, A 1, S 1).

There is even rarer introduction of the aphorism into the sentence by means of the syndetical connection in the interposition (about 4,0\%). In the examples coordinate relations between clauses take preference over subordinate relations. E.g.: Bertram. I think she has: certain it is I liked her, And boarded her $i$ ' the wanton way of youth: She knew her distance and did angle for me, Madding my eagerness with her restraint, As all impediments in fancy's course Are motives of more fancy; and, in fine, Her infinite cunning, with her modern grace, Subdued me to her rate: she got the ring; And I had that which any inferior might At market-price have bought. (AWTEW, A 5, S 2). In single cases coordinate and subordinate relations are combined. E.g.: Cressida. Perchance, my lord, I show more craft than love; And fell so roundly to a large confession, To angle for your thoughts: but you are wise, Or else you love not, for to be wise and love Exceeds man's might; that dwells with gods above. (T\&C, A 3, S 2).

It should be mentioned that in the majority of the examples (about 8,5\%) the syndetical connection is accompanied by the asyndetical connection (in different combinations of coordinate and subordinate relations between clauses) when the aphorism is introduced in the interposition. E.g.: Sir Toby Belch. Approach, Sir Andrew: not to be abed after midnight is to be up betimes; and 'diluculo surgere,' thou know'st. (TW, A 2, S 3); Biron. Why, all delights are vain; but that most vain, Which with pain purchased doth inherit pain: As, painfully to pore upon a book To seek the light of truth; while truth the while Doth falsely blind the eyesight of his look: Light seeking light doth light of light beguile: So, ere you find where light in darkness lies, Your light grows dark by losing of your eyes. Study me how to please the eye indeed By fixing it upon a fairer eye, Who dazzling so, that eye shall be his heed And give him light that it was blinded by. (LLL, A 1, S 1). 
Closeness of qualitative characteristics of the ways of introduction of the aphorism into the text by means of asyndetical and syndetical connections can be explained by a secondary role of the conjunctions in the syntactic structure of the composite sentence containing an aphorism. They are used not as grammar means but as marks of certain semantic relations between clauses. That is the reason for prevailing of the coordinate relation over the subordinate in more than ten times.

CONCLUSION. Individual author's aphorisms which are not original works are used in literary texts. They are divided into content and form dependent units and units independent of the context. The context-dependent aphoristic utterances make $2 / 3$ in the amount of individual author's aphorisms (about 73\%). They are structurally and semantically modified aphoristic units built in the author's context. Independent from the context aphoristic utterances (more than $27 \%$ in the amount of individual author's aphorisms) are defined as autonomous and differentiate into absolutely autonomous and relatively autonomous according to the measure of content and form deformation of the text when they are taken out of it.

Absolutely autonomous aphorisms after taking it out of the text don't remain semantic and structural lacunae and accepted as something independent in the text, even foreign, that's why they are less productive in literary texts (about 32\% in the amount of individual author's aphorisms). Relatively autonomous aphorisms have been differentiated into syntactically uncombined (connected with the text only by content) and combined (connected with the text by content and syntactically). Syntactically uncombined relatively autonomous aphorisms (about 7,5\%) are introduced into the text by the author in the same way as absolutely autonomous aphorisms, the connection of them with the context is marked lexically or semantically. Syntactically combined relatively autonomous aphorisms (about 60,5\%) are parts of composite sentences with asyndetical (rarer) and syndetical (more often) relation. Coordination is the main type of syntactic relation between clauses and is used ten times more often than subordination because coordination increases content and form isolation of relatively autonomous aphorisms in the text.

\author{
Abbreviation \\ AWTEW - «All's Well That Ends Well» \\ COE - «The Comedy of Errors» \\ MAAN - «Much Ado about Nothing» \\ MWW - «The Merry Wifes Of Winsdor» \\ $\mathrm{T} \& \mathrm{C}-\ll$ Troilus and Cressida» \\ TW - «Twelfth Night» \\ WT $-\ll$ Winter's Tale»
}

\title{
LIST OF REFERENCES
}

Elenevskaia, M. N. (1983). Struktura i funktsii aforizma (na materiale angliiskogo iazyka. Ph.D. diss., Leningrad, $190 \mathrm{~s}$. 
Epshtein, M. N. (1987). Aforistika // Literaturnyi entsiklopedicheskii slovar. Moskwa: SovEn, s. 43-44.

Fedorenko, N. T. \& Sokolskaia, L. I. (1990). Aforistika. Moskwa: Nauka, 419 s.

Gluchanko, L. V. (2014). Aforizm kak fenomen yazyka i rechi // Science Looks Ahead. Lugansk: Noulidzh, Vol. 1, s. 26-28.

Gluchanko, L. V. (2017a). Aforisticheskie edinicy v sonetax Uilyama Shekspira // Filologichni studii, Vol. 16, s. 311-317.

Gluchanko, L. V. (2017b). Sposoby upotrebleniya aforisticheskih edinic v sonetax Uilyama Shekspira // Aktualnye problemy prepodavaniya inostrannyh yazykov v vysshej shkole Respubliki Belarus. Mogilev: MGU, s. 160-164.

Gluchanko, L. V. (2019). Semantic variety of aphorisms in William Shakespeare's Sonnets // Романовские чтения - XIII. Romanovskie chteniya - XIII. Mogilev: MGU, s. 144-145.

Ivanov, E. (2016b). Aphorism as a Unit of Language and Speech // EUROPHRAS 2016: Word Combinations in the Linguistic System and Language Use: Theoretical, Methodological and Integrated Approaches, Trier, Germany, August 1-3, 2016: Abstracts. Trier: University of Trier, S. 42.

Ivanov, E. E. \& Petrushevskaia Ju. A. (2015). Etymology of English Proverbs // Journal of Siberian Federal University. Humanities \& Social Sciences, Vol. 8, № 5, pp. 864-872.

Ivanov, E. E. \& Petrushevskaia Ju. A. (2016). English Proverbs: from Literary Texts, in Literary Texts: Etymology, Usage, Variability. Mogilev: MGU, 76 p.

Ivanov, E. E. \& Petrushevskaia Ju. A. (2019). The Etymology and History of English Proverbs. Mogilev: MGU, $80 \mathrm{p}$.

Ivanov, E. E. \& Teslenko, E. G. (2013a). Avtonomnost aforizma v tekste (na materiale proizvedenij U. Shekspira) // Vestnik Poloczkogo gos. un-ta, Seriya A, № 10, s. 86-90.

Ivanov, E. E. \& Teslenko, E. G. (2013b). The Forms of the Aphorisms in the Non-Aphoristic Texts (Autonomous Aphoristic Utterances) // Lingvisticheskie i metodicheskie aspekty prepodavaniya inostrannyh yazykov. Belgorod: BelGUY, s. 92-99.

Ivanov, E. E. (2006) O ponyatiyah "aforisticheskij tekst", "aforistichnost (aforizaciya) rechi" i “aforisticheskij stil” // Vesci Belaruskaga dzyarzh. ped. un-ta, Seryia 1, № 3(49), s. 76-79.

Ivanov, E. E. (2007) Aforizm v tekste i vne teksta: semantika i struktura // Tekst. Iazyk. Chelovek: v 2 t. Mozyr: MGPU, Ch. 1, s. 29-32.

Ivanov, E. E. (2013). O poniatii strukturnoi paradigmy aforizma // Tekst. Iazyk. Chelovek: v 2 t. Mozyr: MGPU, Ch. 1, s. 130-132.

Ivanov, E. E. (2016a). Lingvistika aforizma. Mogilev: MGU, 156 s. 
Ivanov, E. E. (2019). Aspects of empirical understanding of aphorism // RUDN Journal of Language Studies, Semiotics and Semantics, 10(2), 381-401, doi: 10.22363/2313-2299-201910-2-381-401.

Ivanov, E. E. (2020). Aphorism as an Object of Linguistics: the Main Properties // RUDN Journal of Language Studies, Semiotics and Semantics, 11(4), 659-706, doi: 10.22363/2313-22992020-11-4-569-706.

Ivanou, Ya. Ya. (2011). Krylatyya afaryzmy u belaruskaj move: z inshamounyh litaraturnyh i falklornyh krynic VIII st. da n.e. - XX st.: tlumachalny slounik. Magilyou: MDU, 164 s.

Ivanou, Ya. Ya. (2018). Suadnosiny afarystychnyh adzinak i malyh tekstavyh form (na materyyale belaruskaj, ruskaj, polskaj, anglijskaj moh) // Vostochnoslavyanskie yazyki i literatury v evropejskom kontekste - V. Mogilyov: MGU, s. 120-123.

Ivanou, Ya. Ya. (2019a). Tekstavascz yak lingvistychnaya prymeta afarystychnyh adzinak // Izvestiya Gomelskogo gos. un-ta, Seriya «Gumanitarnye nauki», № 4(115), s. 66-72.

Ivanou, Ya. Ya. (2019b). Dyskursiunaya samastojnascz yak lingvistychnaya prymeta afarystychnyh adzinak // Vestnik Poloczkogo gos. un-ta. Seriya A, № 10, s. 100-103.

Jarmuszkiewicz, A. (2015). Aforyzm w nowoczesnej powieści - Proust i Myśliwski // Aforyzm europejski: studia i szkice. Kraków: Pasaże, s. 134-148.

Kudra, B. (2015). Aforyzm w tekście naukowym // Aforyzm europejski: studia i szkice. Kraków: Pasaże, s. 41-52.

Lubimova-Bekman, L. (2001). Rezeption von Aphorismen. Eine textlinguistische Studie. Berlin: Erich Schmidt, $128 \mathrm{~S}$.

Pfeifer, P. C. (1990). Aphorismus und Romanstruktur: zu Robert Musils "Der Mann ohne Eigensehaften". Bonn: Bouvier, $136 \mathrm{~S}$.

\section{For citation:}

Ivanov, E. E. \& Teslenko, E. G. (2021) Autonomous aphorisms (aphorism in the non-aphoristic text) // International Scientific-Pedagogical Organization of Philologists "WEST - EAST" (ISPOP). Scientific Journal “WEST - EAST". Vol.5, N1 (March, 2021). pp. 26-36.

https://doi.org/10.33739/2587-5434-2021-3-1-26-36

\section{Для цитирования:}

Иванов, Е. Е., Тесленко, Е. Г. (2021) Автономные афоризмы (афоризм в неафористическом тексте) // International Scientific-Pedagogical Organization of Philologists "WEST - EAST" (ISPOP). Scientific Journal “WEST - EAST”. Vol.5, N1 (March, 2021). pp. 26-36. https://doi.org/10.33739/2587-5434-2021-3$\underline{1-26-36}$ 
Information about the authors:

Eugene E. Ivanov - PhD of Philological Sciences, Associate Professor, Head of the Department of Theoretical and Applied Linguistics, Mogilev State A. Kuleshov University, Mogilev, Republic of Belarus, e-mail: ivanov-msu@mail.ru

Elena G. Teslenko - Research Student of the Department of Theoretical and Applied Linguistics, Mogilev State A. Kuleshov University, Mogilev, Republic of Belarus.

e-mail: ling-msu@mail.ru

\section{Информация об авторах:}

Евгений Евгеньевич Иванов - кандидат филологических наук, доцент, заведующий кафедрой теоретической и прикладной лингвистики Могилевского государственного университета имени А. В. Кулешова, Республика Беларусь.

эл. почта: $\underline{\text { vvanov-msu@ mail.ru }}$

Елена Григорьевна Тесленко - научный сотрудник кафедры теоретической и прикладной лингвистики Могилевского государственного университета имени А.В. Кулешова, Могилев, Республика Беларусь.

эл. почта: $\underline{\text { ling-msu@ mail.ru }}$

Manuscript received: 13/01/2021

Accepted for publication: $14 / 02 / 2021$

Рукопись получена: 13/01/2021

Принята к печати: 14/02/2021

\section{International Scientific-Pedagogical Organization of Philologists "West-East" ISPOP SCIENTIFIC JOURNAL "WEST-EAST" \\ ISSN (print) - 2587-5434 ISSN (online) - 2587-5523}

